\title{
Does Fund Size Erode Performance? Liquidity, Organizational Diseconomies and Active Money Management
}

\author{
Joseph Chen \\ University of Southern California \\ Harrison Hong \\ Stanford University and Princeton University \\ Ming Huang \\ Stanford University \\ Jeffrey D. Kubik \\ Syracuse University
}

First Draft: April 2002

This Draft: September 2002

\begin{abstract}
We investigate the effect of fund size on performance among active mutual funds. We first document that fund returns, both before and after management fees, decline with fund size, even after adjusting performance by various benchmarks and controlling for other fund characteristics such as turnover and age. We then explore a number of potential explanations for this relationship. We find that the effect of fund size on fund returns is most pronounced among funds that play small cap stocks. Interestingly, performance only depends on fund size and does not decline with family size. Finally, small funds are better than large ones at investing in local companies. We argue that these findings are consistent with both liquidity and organizational diseconomies being important factors behind the documented diseconomies of scale in money management.
\end{abstract}

We are indebted to Jeremy Stein for his many insightful comments. We are also grateful to Paul Pfleiderer, Jack MacDonald, Jonathan Reuter, Jiang Wang, Haicheng Li, Lu Zheng and seminar participants at MIT, Michigan, Illinois, and Stanford for their helpful comments. Hong also thanks the University of Michigan for their hospitality during his visit when the paper was written. Please address inquiries to Harrison Hong at hhong@ princeton.edu. 
In this paper, we investigate the effect of fund size on performance among active mutual funds. This issue is an important one for the mutual fund industry, which is becoming an increasingly important part of the financial markets. A better understanding of the economies of scale in this industry would naturally be useful for investors in determining which funds to hold. At the same time, it may help practitioners to optimize on a variety of decisions such as when to close funds and what compensation to give to managers. For instance, some observers worry that managerial compensation in this industry, which is typically a fixed percentage of assets under management, may have adverse sideeffects in the presence of diseconomies of scale (see, e.g., Becker and Vaughn (2001)). One such adverse side-effect is that managers have a strong incentive to grow fund size at the expense of achieving higher returns for their investors. Therefore, understanding the economies of scale for mutual funds is an important first step towards addressing such critical issues.

While the effect of fund size on performance is obviously an important question for the mutual fund industry and its investors, it has received little research attention to date. Indeed, there appears to be disparate views among practitioners on this issue. Some point out that there are advantages to fund size such as more resources for research and lower expense ratios (see, e.g., Fredman and Wiles (1998)). Others believe that a large asset base erodes fund performance because of trading costs associated with liquidity (see, e.g., Lowenstein (1997)). A small fund can easily put all of its money in its best ideas, but a lack of liquidity forces a large fund to have to invest in its not-sogood ideas. Big funds may also have to take larger positions per stock than is optimal, which makes it more difficult for them to get in and out of stocks than small funds. 
The little research that has been done is somewhat mixed. A number of studies have documented that fund managers do have the ability to beat the market before management fees (Grinblatt and Titman (1989), Grinblatt, Titman and Wermers (1995), Daniel, Grinblatt, Titman and Wermers (1997)). Moreover, mutual fund investors are apparently naïve in that they pay too much in fees, which results in their risk-adjusted fund returns being significantly negative (Jensen (1968), Malkiel (1995), Gruber (1996)). ${ }^{1}$ To the extent that there are diseconomies of scale, we expect fund size to be inversely related to gross fund returns (before management fees are deducted). Since investors may not be sophisticated enough to avoid large funds, we also expect this inverse relationship to hold for net fund returns (after such fees are deducted). ${ }^{2}$

However, there is little direct evidence to date that fund size erodes performance. Using a small sample from 1974-1984, Grinblatt and Titman (1989) find some evidence that gross fund returns (constructed only from fund stock holdings) decline with fund size, but do not find a similar effect using net fund returns. ${ }^{3}$ Other studies use simulations to show that the asset base can significantly erode performance by assuming that bigger funds have to take larger positions in the same set of stocks and hence suffer more from price impact (see, e.g., Perold and Solomon (1991)). Needless to say, there is no consensus on this issue.

Using mutual fund data from 1962-1999, we first use cross-sectional variation to see whether future performance depends on current fund size. We find that fund

\footnotetext{
${ }^{1}$ A related literature finds that mutual fund investors are susceptible to marketing (see, e.g., Gruber (1996), Sirri and Tufano (1998) and Zheng (1999)).

${ }^{2}$ See discussion in Gruber (1996) and Berk and Green (2002) for related analysis on the effects of diseconomies of scale and fund flows for persistence in fund performance.

${ }^{3}$ Morningstar often release research reports that find that fund size indeed erodes performance, even measured on a net fund return basis (for these reports, see Morningstar.com). These reports also offer investors tips on which small mutual funds to buy.
} 
performance is negatively correlated with total net assets, where performance is measured with both gross and net fund returns. For instance, using CAPM-adjusted, four-quarter gross returns, funds in the smallest fund size quintile outperform funds in the largest fund size quintile by an average of $2.07 \%$ over the next year. The analogous number using four-quarter net returns is $1.28 \%$ over the next year. The inverse relationship between fund size and performance is somewhat dampened but is still economically and statistically significant when we use other performance benchmarks. For instance, the corresponding numbers for gross and net fund returns adjusted using the Fama-French (1993) three-factor model are $1.36 \%$ and 58 basis points over the next year, respectively.

There are of course a number of potential explanations for why fund performance is inversely related to assets under management. So we proceed to narrow down the set of potential explanations. The first hypothesis that we consider is that asset base is a proxy for other fund characteristics that affect performance. For instance, size may be picking up the degree to which funds are active. To address such heterogeneity, we regress the various adjusted returns on not only fund size (as measured by the log of total net assets), but also include in the regressions fund turnover, which is a considered a proxy for fund activity, as well as age, expense ratio and total load. While some of these other fund characteristics are statistically significant in our regressions, they do not really affect our estimate of fund size on performance. Even though the dataset we use is survivorship bias free, there may still be other biases that affect inference among the smallest funds (see Elton, Gruber and Blake (2000)). When we drop these smallest funds from our analysis, our findings are largely unchanged. 
Even with these controls, there are still a number of potential explanations that might be consistent with the inverse relationship between size and performance. For instance, perhaps investors who invest in large funds are less discriminating about performance than small funds. To further narrow down the set of explanations, we proceed to test a direct implication of the hypothesis that fund size erodes performance because of liquidity. If this hypothesis is true, then size ought to erode performance much more for small cap funds, i.e. funds that play small stocks, since small stocks are much more illiquid than large ones. Consistent with the liquidity hypothesis, we find that fund size matters more for performance among small cap funds than other funds. Indeed, for large cap funds, size does not significantly affect performance. This finding strongly indicates that liquidity plays an important role in the documented diseconomies of scale.

We then delve deeper into the liquidity hypothesis by observing that liquidity means that big funds need to find more stock ideas than small ones but liquidity itself may not completely explain why they cannot go about doing this, i.e. why they cannot scale. Presumably, a large fund can afford to hire additional managers so as to cover more stocks. It can thereby generate additional good ideas so that it can take small positions in lots of stocks as opposed to large positions in a few stocks. Indeed, the vast majority of small cap stocks are untouched by mutual funds (see, e.g., Hong, Lim and Stein (2000), Chen, Hong, and Stein (2002)). So there is clearly scope for even very large funds to generate new ideas. Put another way, why cannot two small funds merge into one large fund and still have the performance of the large one be equal to the sum of the two small ones? 
We hypothesize that in addition to liquidity, fund size erodes performance because of organizational diseconomies. To make things concrete, imagine that there is a small fund company $\mathrm{X}$ with one fund operated by one manager (also the founder) who picks the stocks. Since the fund is small, the founder along with a couple of analysts can easily invest the assets under management by generating a few stock ideas. Now imagine that there is a large fund $\mathrm{Y}$ in which the founder no longer has the capacity to invest all the money. So the founder needs other managers to help him manage the fund. For fund $\mathrm{Y}$, the stock picks need to be coordinated among many more agents and therefore organizational form (e.g. flat versus hierarchical forms) becomes important. As such, organizational diseconomies may arise. There are many types of organizational diseconomies that lead to different predictions on why small organizations outperform large ones. ${ }^{4}$

One type, known as hierarchy costs, may be especially relevant for mutual funds (see, e.g., Aghion and Tirole (1997), Stein (2002)). The basic idea is the following. If the founder of the large fund $\mathrm{Y}$ in the example above, who is at the top of the hierarchy, undercuts the decisions of the other managers at the bottom of the hierarchy, then they may not put as much effort into their research. As a result, the other managers' efforts to uncover information or new ideas in this setting are diminished relative to a situation in which they manage their own smaller funds. So all else equal, large funds perform worse than small ones. ${ }^{5}$

\footnotetext{
${ }^{4}$ See Bolton and Scharfstein (1998) and Holmstrom and Roberts (1998) for surveys on the boundaries of the firm that discuss such organizational diseconomies.

${ }^{5}$ More generally, the idea that agents' incentives are weaker when they do not have control over asset allocation or investment decisions is in the work of Grossman and Hart (1986), Hart and Moore (1990) and Hart (1995).
} 
To see whether organizational diseconomies due to hierarchy costs may be important in addition to liquidity, we look at whether family size affects performance. If liquidity is the only factor driving our fund size finding, then we would expect large families (in terms of total net assets) to also do worse than small families since a family can be thought of as one big fund with its portfolio comprised of its constituent funds. In contrast, the hypothesis of organizational diseconomies related to hierarchy costs predicts that scale only affects fund performance and not family performance since stock picking decisions typically are made at the fund level and not at the family level. ${ }^{6}$ Consistent with this hypothesis, we find that large families do not do worse than small ones.

Finally, we present some additional evidence that is consistent with the importance of organizational diseconomies in explaining our fund size finding. Stein (2002) argues that in the presence of hierarchy costs, small organizations ought to outperform large ones at tasks that involve the processing of soft information, i.e., information that cannot be directly verified by anyone other than the agent who produces it. To see whether this is true for mutual funds, we compare the investments of large and small funds in local stocks (stocks nearby to where a fund is headquartered). Investing in such companies likely requires that the organization process soft information as opposed to a strictly quantitative investing approach, which would typically process hard information like price-to-earnings ratios. We find that small funds do better at picking local stocks than large funds, especially among small cap funds.

\footnotetext{
${ }^{6}$ For most families, the money managers make the allocation decisions for a fund and the family serves as a way to economize on marketing or other fixed costs.
} 
Our paper proceeds as follows. We describe the data in Section I and the performance benchmarks in Section II. In Section III, we present our empirical findings and explore which explanations our findings support. We conclude in Section IV.

\section{Data}

Our primary data on mutual funds comes from the Center for Research in Security Prices (CRSP) Mutual Fund Database for the years 1962-1999. Following many prior mutual fund studies, we restrict our analysis to diversified U.S. equity mutual funds. We exclude from our analyses bond funds, international funds and specialized sector funds. ${ }^{7}$ We also require that the funds in our sample have at least one year of reported fund returns and information on fund size. ${ }^{8}$

Table 1 reports summary statistics on this mutual fund sample. Panel A reports mean statistics. In an average month, our sample includes about 634 funds with average total net assets (TNA) of 285.6 million dollars and average expense ratios (as a fraction of year-end TNA) of 98 basis points per year. In addition, the database reports turnover for each fund (defined as the minimum of purchases and sales over average TNA for the calendar year), which averages 55.8 percent per year. These funds charge a total load of about 4.45 percent (as a percentage of new investments) on average. The average fund

\footnotetext{
${ }^{7}$ More specifically, we select mutual funds in the CRSP Mutual Fund database that have reported one of the following investment objectives at any point in their lives. We first select mutual funds with Investment Company Data, Inc. (ICDI) mutual fund objective of 'aggressive growth', 'growth and income', or 'long-term growth'. We then add in mutual funds with Strategic Insight mutual fund objective of 'aggressive growth', 'flexible', 'growth and income', 'growth', 'income-growth', or 'small company growth'. Finally, we select mutual funds with Wiesenberger mutual fund objective code of 'G', 'G-I', 'GI-S', 'G-S', 'GCI', 'I-G', 'I-S-G', 'MCG', or 'SCG'.

${ }^{8}$ We require one-year of past fund returns as we will need it to form benchmark portfolios based on past performance. We have also replicated our analysis without this restriction. The only difference is that the sample includes more small funds. But the results are unchanged. Moreover, a mutual fund that has different share classes enters the database multiple times depending on the number of share classes it has. We clean the data by eliminating redundant observations for a particular mutual fund.
} 
age is about 16.6 years. We have a total of 2863 funds and 24,160 fund years in our sample. These summary statistics are similar to those reported in Carhart (1997). ${ }^{9}$ So we can take comfort that our sample is similar to existing mutual fund studies.

Table 1 also reports these summary statistics for each mutual fund size quintile as well as for the sample of all mutual funds excluding the smallest quintile. The interesting thing to note is that there is quite a substantial spread in fund size. The funds in the smallest quintile have an average TNA of only about six million dollars, whereas funds in the top quintile have an average TNA of over one billion dollars. Since the funds in the smallest quintile are quite small, we have to be cognizant of the possibility that these funds may exhibit certain performance biases.

Panel B of Table 1 reports the time-series averages of the cross-sectional correlations between various fund characteristics. The obvious patterns are that the expense ratio varies inversely with fund size $(-0.37)$, while total load and fund age vary positively with fund size ( 0.19 and 0.41 respectively). The relationship between fund size and turnover is ambiguous (only 0.03). Nonetheless, it is apparent from Panel B that we need to control for these fund characteristics in estimating the cross-sectional relationship between size and performance. Panel $\mathrm{C}$ reports the analogous numbers for only funds in fund size quintiles 2-5. The results are similar to those in Panel B.

\section{Fund Performance Benchmarks}

We employ a number of performance benchmarks. Panel A of Table 2 reports the summary statistics for the various portfolios that make up our performance benchmarks.

\footnotetext{
${ }^{9}$ At the end of 1993, we have about 1319 funds in our sample, very close to the number reported by Carhart (1997).
} 
Among these are the returns on the CRSP value weighted stock index net the one-month Treasury rate (VWRF), the Fama-French (1993) SMB (small stocks minus large stocks) and HML (high book-to-market stocks minus low book-to-market stocks) portfolios, and a Jegadeesh and Titman (1993) momentum portfolio MOM12 (buy/sell based on past twelve month returns and hold for one-month). The summary statistics for these portfolios are similar to those reported in other mutual fund studies.

Since we are interested in the relationship between fund size and performance, we begin by sorting mutual funds at the beginning of each month based on the quintile rankings of their previous-month TNA. ${ }^{10}$ We then track these five portfolios for one month and use the entire time series of their monthly net returns to calculate the loadings to the various factors for each of these five portfolios.

For each month, each mutual fund inherits the loadings of the one of these five portfolios that it belongs to. In other words, if a mutual fund stays in the same size quintile through out its life, its loadings remain the same. But if it moves from one size quintile to another during a certain month, it then inherits a new set of loadings with which we adjust its next month's performance.

Panel B reports the loadings of the five size sorted mutual fund portfolios using Capital Asset Pricing Model (CAPM) of Sharpe (1964):

$$
r_{i, t}=\alpha_{i}+\beta_{i} \mathrm{VWRF}_{t}+e_{i, t}
$$

\footnotetext{
${ }^{10} \mathrm{We}$ also sort mutual funds by their past twelve-month returns to form benchmark portfolios. Our results are unchanged when using these benchmark portfolios. We omit these results for brevity.
} 
where $r_{i, t}$ is the (net fund) return on our five size-sorted mutual fund portfolios in period $t$ in excess of the one-month T-bill return. Notice that there is only a slight variation in the market beta from the smallest to the largest size portfolio: the smallest portfolio has a somewhat smaller beta, but not by much. As other papers have found, the average mutual fund has a beta of around 0.91 , reflecting the fact that mutual funds hold some cash or bonds in their portfolios.

Moreover, like other papers, net fund returns are on average negative. Using market-adjusted returns, funds under perform the market by about eight basis points a month or 96 basis points a year. Using CAPM-adjusted returns, funds under perform only by three basis points a month or 36 basis points a year. More importantly, we see that there is already a pattern in which performance appears to decrease with fund size. Using either market-adjusted or CAPM-adjusted returns, the spread between funds in fund size quintile 1 and 5 is about eight basis points a month or 96 basis points a year.

We caution against making too much of these patterns since they are only monthly returns and are not always monotonically decreasing in fund size. Moreover, it is not clear whether they will persist when we look at longer horizons. Hence, we will look more carefully at these patterns below by using four-quarter returns.

We consider two additional performance measures, the Fama-French three-factor model and this three-factor model augmented by a momentum factor, MOM12, as in Carhart (1997):

$$
\begin{aligned}
& r_{i, t}=\alpha_{i}+b_{i} V_{W R F}+s_{i} S M B_{t}+h_{i} H_{M L}+e_{i, t}
\end{aligned}
$$

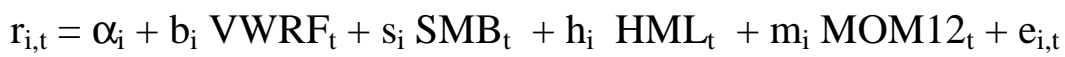


where SMB, HML and MOM12 are returns on value-weighted, zero-investment, factormimicking portfolios for size, book-to-market equity and one-year momentum in stock returns.

We want to emphasize that the interpretation of these performance measures (unlike the CAPM) is far from clear. A strict risk-adjusted returns interpretation is unwarranted since there is vibrant debate over how to interpret the Fama-French threefactor model. This is especially true for the MOM12 factor since most of the work over the last five years on momentum strongly argues against a risk-based interpretation.

More plausibly, we can think of these adjustments as informing us as to the source of mutual fund performance. But to be conservative, we will not give mutual funds credit for these strategies and assume that they just happen to be playing these strategies.

Panel $\mathrm{C}$ reports the loadings for these two models. We see that small funds tend to have higher loadings on SMB and HML, but large funds tend to load heavier on momentum. For instance, the loading on SMB for the three-factor model for funds in quintile 1 is 0.29 while the corresponding loading for funds in quintile 5 is 0.07 . And whereas large funds load negatively on HML (-0.06 for the largest funds), the smallest funds load positively on HML (0.04). (Falkenstein (1996) also finds some evidence that larger funds tend to play large and glamour stocks by looking at fund holdings.)

When we look at the Fama-French three-factor alphas, the performance spread between small and large funds understandably shrinks, but it looks like there is still a healthy spread of about four basis points a month or 48 basis points a year. When we 
look at the four-factor alphas, the spread in performance between small and large funds is about six basis points a month, which is only slightly smaller than the corresponding figure using market-adjusted and CAPM-adjusted returns.

We have also re-done all of our analysis by calculating these loadings while using gross fund returns instead of net fund returns. Monthly gross fund returns are calculated by adding back the expenses to net fund returns by taking the year-end expense ratio, dividing it by twelve and adding it to the monthly returns during the year. The results are very similar to using net fund returns. So for brevity, we will just use the loadings summarized in Table 2 to adjust fund performance (whether it be gross or net returns) below.

Moreover, we have also calculated loadings for each mutual fund. Using the entire time series of a particular fund (we require at least 36 months of data), we calculate the loadings using equations (1)-(3). This technique is not as good in the sense that we have a much more intensive requirement on selection and the estimated loadings tend to be very noisy. In any case, our results are unchanged, so we omit these results for brevity.

\section{Empirical Results}

\section{A. Baseline Effect of Fund Size on Performance}

Our empirical strategy utilizes cross-sectional variation in fund size to see whether fund performance declines with fund size. Now, we could have adopted a fixedeffects approach by looking at whether changes in a fund's performance are related to changes in its size. However, such an approach is subject to a regression-to-the-mean 
bias. A fund with a year or two of lucky performance will experience an increase in fund size. But performance will regress to the mean, leading to a spurious conclusion that an increase in fund size is associated with a decrease in fund returns. Measuring the effect of fund size on performance using cross-sectional regressions is less subject to such biases and may be conservative in that large funds are likely to be good funds, i.e. they would not have become large otherwise.

One potential worry with using cross-sectional variation is that funds of different sizes may be naively playing certain profitable strategies such as the Fama-French (1993) factors or momentum. A very conservative way to deal with this worry is to not give mutual funds any credit for these strategies. So we adjust mutual fund performance by the Fama-French three-factor model and this model augmented with the momentum factor of Jegadeesh and Titman (1993) as in Carhart (1997).

We begin our analysis on whether fund performance declines with fund size in Table 3. Panel A reports the mean gross 4-quarter fund performance by the five fund size quintiles. The first row reports performance using simple market-adjusted returns. Notice that performance monotonically declines with fund size, with funds in the smallest quintile having an average four-quarter return of $1.13 \%$ while funds in the largest quintile under-performs the market by 72 basis points. The difference of $1.85 \%$ per year is both economically and statistically significant. Similar results hold using CAPM-adjusted returns: the spread between the smallest and the largest quintile is now $2.07 \%$.

Looking at the three-factor and four-factor adjusted returns, we still see that performance declines with size across the five size quintiles. The interesting thing to note is that this decline is most muted when using the three-factor adjusted returns. This 
is not surprising since small funds tend to load positively on SMB and HML, thereby leading to a less dramatic spread in performance between small and large funds. Nonetheless, the difference in performance between the smallest and largest size quintile funds is still $1.36 \%$ using the three-factor model adjusted returns and nearly $1.62 \%$ using the four-factor model adjusted returns and the difference remains statistically significant in both cases.

Panel B of Table 3 reports the mean net fund performance by the five fund size quintiles. The key thing to note is that size still has an effect on performance, though the spread is less dramatic than using gross fund returns. For instance, the difference between the smallest and largest quintile is still a healthy $1.08 \%$ percent a year using market-adjusted returns and $1.28 \%$ using CAPM-adjusted returns. The corresponding numbers for the three-factor model adjusted and four-factor model adjusted returns are 58 basis points and 84 basis points a year, respectively. While the figures obtained using net fund returns are smaller than those obtained using gross fund returns, they are nonetheless statistically and economically significant. Again, remember that the interpretation of these latter two adjustments is far from clear. We are being very conservative in not giving mutual funds credit for these strategies.

\section{B. Evaluating Explanations for Why Performance Declines with Fund Size}

Having established that performance declines with fund size, we next turn to evaluating different potential explanations for this finding.

\section{Fund Size as a Proxy for Other Fund Characteristics}


The first possibility that we consider is that fund size is a proxy for other fund characteristics that might be related to performance. For instance, fund size may be measuring whether a fund is active or passive. While we have tried our best to rule out passive funds in our sample construction, it is possible that some funds may just be indexers. And if it turns out that indexers happen to be large funds because more investors put their money in such funds, then size may be picking up differences in the degree of activity among funds. One way to address this explanation is to use fund turnover as a proxy for whether a fund is active or passive.

More generally, since we have a number of other fund characteristics such as fund age, expense ratio, and total load, we can measure the effect of size on performance by controlling for these characteristics in a regression framework. In Table 4, we run a cross-sectional regression of each fund's performance (measured in percents) on size (as measured by the Log of TNA) and these other fund characteristics. To the extent that the relationship between size and performance is induced by other fund characteristics, we expect the coefficient in front of Log TNA to be significantly dampened.

Panel A reports the results for gross fund returns. Notice that the coefficient in front of Log TNA is negative and statistically significant. The coefficients are roughly 0.25 and -0.29 using market-adjusted and CAPM-adjusted returns, respectively. Since one standard deviation of Log TNA is 1.83 , a two standard deviation shock to fund size means that CAPM measured performance changes by -0.29 of 3.7 , or $-1.07 \%$, which is similar to the magnitude obtained without the controls. For the other two performance benchmarks, the coefficients are -0.15 and -0.2 , respectively, and are also statistically significant. 
The other interesting thing to note is that the coefficient in front of fund age also comes in with a negative sign and is also statistically significant. So older funds do worse than younger funds. There are a number of interpretations for this, such as more experienced managers exerting less effort than younger managers for career concerns reasons (see, e.g., Chevalier and Ellison (1999), Hong, Kubik and Solomon (2000)). The other thing to note is that the coefficient in front of total load comes in with a significant, positive sign, while the coefficient for fund turnover does not. One interpretation for this is that perhaps total load captures whether a fund is active or passive better than fund turnover. The coefficient in front of expense ratio is not significant.

Panel B reports the results for net fund returns. The coefficient in front of Log TNA is still negative. It is statistically significant for all performance benchmarks expect for the three-factor model. Nonetheless, the magnitudes implied by these coefficients are still economically interesting. The coefficients in front of turnover, age and total load are the same as for gross fund returns. However, the coefficient in front of expense ratio is now negative, though still not statistically significant.

\section{Omission Bias}

While our mutual fund data is survivorship-bias free, Elton, Gruber and Blake (2000) suggests that there is still a potential for a subtle form of survivorship bias. They argue that among small funds less than 15 million dollars, some only report fund information on an annual basis and those who only report annually under-perform those who report quarterly or monthly. Hence, if we restrict our sample to mutual funds that have monthly observations, then we will be susceptible to a form of survivorship bias, 
which they term an omission bias. When we use monthly, overlapping observations, we are guilty of selecting those funds that report information monthly.

This critique really only applies to funds in quintile 1 , since funds in the other quintiles typically have fund sizes greater than 15 million dollars. We address this critique by re-doing our analysis using only funds between fund size quintiles 2-5. Panel C of Table 4 reports the results for gross fund returns and Panel D reports the results for net fund returns.

Our findings regarding fund size are qualitatively unchanged. The coefficients using the two samples are quite similar (compare Panel A with C and Panel B with D). The slight difference is that the coefficient using the four-factor adjusted return is smaller for the sample with only funds from size quintiles 2-5. More interestingly, the coefficient in front of fund turnover is statistically significant when we use the truncated sample, while the coefficient in front of fund age declines in significance

Unfortunately, controlling for different benchmarks and other fund characteristics can only rule out so many explanations. There are still a number of others that are difficult to rule out with this approach. One potential remaining explanation for the sizeperformance relationship not ruled out by our fund characteristics controls is that large and small funds cater to different clienteles. Perhaps investors in large funds are less discriminating about returns than investors in small funds. One reason why this might be the case is that large funds such as Magellan are better at marketing and are able to attract investors through advertising. In contrast, small funds without such marketing operations may need to rely more on better performance to attract and maintain investors. 
Another explanation not ruled out by the analysis above is that fund size is inversely related to performance because of fund incentives to lock in assets under management after a long string of good past performances. ${ }^{11}$ When a fund is small and has little reputation, the manager goes about the business of stock picking. But as the fund gets large because of good past performance, the manager may for various reasons lock in his fund size by being passive (or a "closet indexer" as practitioners put it).

\section{Liquidity Hypothesis}

In order to narrow down the list of potential explanations, we pursue the auxiliary implications of a particular hypothesis. In this vein, we look to see whether the liquidity hypothesis often articulated by practitioners is an important determinant of the documented diseconomies of scale.

To the extent that liquidity is driving the our findings above, we would expect to see that fund size matters much more for performance for funds that play small cap stocks than funds that play large cap stocks. The reason is that small cap stocks are notoriously illiquid. As a result, funds that play small cap stocks are more likely to need new stock ideas with asset base growth, where large funds can more simply increase their existing positions without being hurt too much by price impact.

Importantly, existing research finds that there is little variation in incentives across small cap and other funds (see, e.g., Almazan, et.al. (2001)). Hence, this

\footnotetext{
${ }^{11}$ More generally, it may be that after many years of good performance, bad performance follows for whatever reason. We are offering here a plausible economic mechanism for why this might come about. The ex ante plausibility of this alternative story is, however, somewhat mixed. On the one hand, the burgeoning empirical literature on career concerns suggests that fund managers ought to be bolder with past success (see, e.g., Chevalier and Ellison (1999) and Hong, Kubik and Solomon (2000)). On the other hand, the fee structure means that funds may want to lock in assets under management because investors are typically slow to pull their money out of funds.
} 
prediction ought to help us discriminate between our hypothesis and the alternative oneagent story involving fund incentives. Moreover, since small cap funds tend to do better than other funds, it is not likely that our results are due to investors in small cap funds being more irrational than those investing in other funds.

In the CRSP Mutual Fund Database, each fund self-reports its style, and one of the categories is Small Cap Growth. So, we identify funds in our sample as either Small Cap Growth if it has ever reported itself as such or Not Small Cap Growth. (Funds rarely change their self-reported style.) On average, there are 67.3 such funds each year. Recall that the corresponding number for the overall sample is 634. So, Small Cap Growth represents a small but healthy slice of the overall population. Also, the average TNA of these funds is 162 million dollars with a standard deviation of 346.6 million dollars. The average TNA of a fund in the overall sample is 285.6 million dollars with a standard deviation of 866.9 million dollars. So, Small Cap Growth funds are somewhat smaller than the typical fund. But they are still quite big and there is a healthy fund size distribution among them, so that we can measure the effect of fund size on performance.

Table 5 reports what happens to the results in Table 4 when we augment the regression specifications by including a dummy indicator $\operatorname{Ind}_{\{\text {not SCG }}$ (that equals one if a fund is not Small Cap Growth and zero otherwise) and an additional interaction term involving Log TNA and $\operatorname{Ind}_{\{\text {not SCG\}}}$. Panel A reports the results for gross, four-quarter returns. To be conservative, we report the results using the truncated sample of funds in fund size quintiles 2-5. (The results for fund size quintiles 1-5 are similar and we omit them for brevity.) Notice that the coefficient in front of $\operatorname{Ind}_{\{\text {not } S C G\}}$ is negative and statistically significant. This makes sense since small cap stocks have historically had 
higher returns than large cap stocks. The coefficient in front of log fund size is about -0.7 (across the four performance benchmarks). Importantly, the coefficient in front of the interaction term is positive and statistically significant (about 0.57 across the four performance benchmarks). This is the sign predicted by our liquidity hypothesis since it says that for Non Small Cap Growth funds, there is a smaller effect of fund size on performance. The effect is economically interesting as well. Since the two coefficients, 0.7 and 0.57 , are similar in magnitude, this means that a sizeable fraction of the effect of fund size on performance comes from small cap funds. The results using net fund returns reported in Panel B are similar.

We have also conducted additional analyses in which we look at the effect of fund size on performance among large cap funds. Such funds are identified in the database as Growth and Income funds. We also find that fund size matters little among this subset of funds, consistent with liquidity hypothesis. We omit these results for brevity.

\section{Liquidity and Organizational Diseconomies: The Effect of Family Size on}

\section{Performance}

We next delve a bit deeper into the liquidity hypothesis. As we pointed out in the beginning of the paper, liquidity means that large funds need to find more stock ideas than small funds, but it does not therefore follow that they cannot. Indeed, large funds can go out and hire more managers to follow more stocks. To see that this is possible, we calculated some basic summary statistics on fund holdings by fund size quintiles. Since the CRSP Mutual Fund Database does not have this information, we turn to the CDA Spectrum Database on Mutual Fund Holdings. We take data from the end of September 
1997 and calculate the number of stocks held by each fund. The median fund in the smallest quintile has about 16 stocks in its portfolio, while the largest fund has only about 66 stocks in its portfolio. These numbers make clear that large funds do have to find more stock ideas. At the same time, they also make clear that there is plenty of scope for large funds to find other stocks given the thousands of stocks available.

We pointed out in the beginning of the paper, organizational diseconomies due to hierarchy costs may be important, in addition to liquidity, in explaining the documented diseconomies of scale. To see whether this is the case, we look at whether family size affects performance. If liquidity is the only factor driving our fund size finding, then we would expect large families (in terms of total net assets) to also do worse than small families since a family can be thought of as one big fund with its portfolio comprised of its constituent funds. In contrast, the hypothesis of organizational diseconomies related to hierarchy costs predicts that scale only affects fund performance and not family performance since stock picking decisions typically are made at the fund level and not at the family level.

We test this prediction in Table 6 . We augment our baseline regressions in Table 4 by adding in two additional independent variables. The first is Log of the family size that the fund belongs to, where family size is simply the total net assets of funds in a family. ${ }^{12}$ The second is this variable interacted with Log of fund size. First, it does not appear that family size plays a large role in predicting fund returns above and beyond fund size since the coefficient in front of Log family size (while negative) is not statistically significant. In contrast, our fund size variable remains economically and

\footnotetext{
${ }^{12}$ If large families like Fidelity also tend to have larger funds, then the family size variable is correlated with the fund size variable and both may come in and fight it out in explaining performance.
} 
statistically significant as before. Indeed, if anything, performance increases with family size since the coefficient in front of the interaction term is positive. One interpretation for this is that since stock picking typically happens at the fund level, there are no such diseconomies at the family level. Instead, larger families allow for better utilization of marketing and administrative costs.

Interestingly, the findings in Table 6 also allow us to discriminate among different types of organizational diseconomies. One set of diseconomies from the work of Williamson $(1975,1988)$ includes bureaucracy and related coordination costs. If Williamsonian style organizational diseconomies are behind the relationship between size and performance, one expects that fund size matters more for performance among funds that belong to large families, since bureaucracy ought to be more important in huge fund complexes. One would expect that the coefficient in front of the interaction term of fund size and family size to be negative and statistically significant. Instead, the coefficient is of the wrong sign.

In work completed independently, IvKovic (2002) also finds that family size does not affect performance. In his analysis of family size, he happened to control for fund size and found that fund size indeed erodes performance. Though the goal of his paper was not to examine fund size, it is comforting to know that some of our baseline results have been independently verified. Moreover, his analysis along with ours suggest that fund families seem to play an important role in economizing on marketing costs as opposed to having anything having to do with fund performance.

\section{Organizational Diseconomies and Soft Information}


Finally, we take a closer look at the effect of organizational diseconomies due to hierarchy costs on fund performance. Stein (2002) argues that in the presence of such hierarchy costs, small organizations ought to outperform large ones at tasks that involve the processing of soft information, i.e., information that cannot be directly verified by anyone other than the agent who produces it. If the information is soft, then agents have a hard time convincing their superiors of their ideas. To the extent that fund size erodes performance because of the type of organizational diseconomies pointed out in Stein (2002), we expect that small funds are better than large ones at the processing of soft information.

To test this prediction, we compare the investments of large and small funds in local stocks (stocks nearby to where a fund is headquartered). Investing in such companies requires that the organization process soft information as opposed to a strictly quantitative investing approach, which would typically process hard information like price-to-earnings ratios. Our work in testing this prediction builds on the very interesting work of Coval and Moskowitz (2001) whose central thesis is that mutual fund managers do have ability when it comes to local stocks. They find that funds can earn superior returns on their local investments. They also document that small funds are more likely than large ones to benefit from these investments. We expect to find that small funds do better at picking local stocks than large funds, especially among small cap funds, after controlling for various fund and family characteristics.

As we mentioned above, the CRSP Mutual Fund Database does not have any information about fund positions in individual stocks. So we again turn to the CDA Spectrum Database that has the stock positions of funds reported on a quarterly basis. 
We take two years or eight quarters worth of data from 1997-1998 and analyze the effect of fund size on the composition of fund stock holdings and the performance of these holdings. Since we do not intend to compare the performance of the overall fund with the performance of their stock holdings, we do not merge these two databases. Indeed, others such as Wermers (2000) have done so and a number of observations are lost in the merge. Moreover, the process of merging these two databases is quite cumbersome.

The CDA Spectrum Database does not have the same information on fund characteristics as the CRSP Mutual Fund Database. Luckily, we are able to construct from the fund stock holdings data a proxy for the fund size, which is simply the value of the fund's stock portfolio at the end of a quarter. While this is not exactly the same as the asset base since funds hold cash and bonds, we believe that the proxy is a reasonable one since we will look at the tails of the size distribution to draw inferences, i.e. compare very small funds to other funds. Moreover, the noise in our fund size measure does not obviously bias our estimates.

In addition, we can construct better style controls for each fund by looking at their stock holdings. We use a style measure constructed by Daniel, Grinblatt, Titman and Wermers (1997), which we call the DGTW style. For each month, each stock in our sample is characterized by where they fall in the (across stocks) size quintiles, book-tomarket quintiles and momentum quintiles. So a stock in the bottom of the size, book-tomarket and momentum quintiles in a particular month would be characterized by a triplet $(1,1,1)$. For each fund, we can characterize its style along the size, book-to-market and momentum dimension by taking the average of the DGTW characteristics of the stocks in their portfolio weighted by percentage of the value of their portfolio that they devote to 
each stock. We can then define a Small Cap fund as one whose DGTW measure falls in the bottom 10 percent when compared to other funds.

In Table 7, we see whether the local stocks picked by small funds do better than those picked by large funds, where locality is defined relative to the headquarter of the fund as in Coval and Moskowitz (2001). More specifically, a stock is considered a local fund investment if the headquarter of the company is in the same Census region as the mutual fund's headquarter. ${ }^{13}$ The dependent variable is the return to the fund's investments in local stocks. The first independent variable is Small Fund, which is a dummy variable that equals one if the fund is in the bottom $10 \%$ of the fund size distribution. Small Cap Fund equals one if a fund has an average DGTW score for its stocks that is in the bottom $10 \%$ across funds. The regressions always have Fund City Effects as controls. In column (1), we find that small funds and small cap funds do better at investing in local stocks. In column (2), we add an interaction term involving these two variables and find that the performance difference between small funds and other funds is especially big in small cap funds.

One interesting question is the degree to which these findings are driven by a family size effect since larger funds are likely to be located in larger families. In column (3), we add a family size control measured by the number of funds in the family. Similar results obtain using total net assets for the family. This does not do much to our variables of interest though it is positive but only marginally significant. To be even more

\footnotetext{
${ }^{13}$ There are nine Census regions: New England (CT, ME, NH, RI, VT); Middle Atlantic (NJ, NY, PA); East North Central (IL, IN, MI, OH, WI); West North Central (IA, KS, MN, MO, NE, ND, SD); South Atlantic (DE, FL, GA, MD, NC, SC, VA, WV); East South Central (AL, KY, MS, TN); West South Central (AR, LA, OK, TX); Mountain (AZ, CO, ID, MT, NE, NM, UT, WY); and Pacific (AK, CA, HI, OR, WA).
} 
conservative, we introduce Family Size Effects that are dummies for where a fund's family falls in the deciles of family size. Again, the estimates of interest are unchanged.

The findings in Tables 7 suggest that the performance differences between small and large funds have something to do with their different ability to invest in local stocks. Moreover, they indicate that our fund size findings have little to do with family size. Note that Table 7 only reports the results using the cross-section in September 1997. We have replicated our analysis using the other quarters in from 1997-1998. The results are very robust across quarters.

Our analysis here is similar to the work of Berger et.al. (2002). They test the idea in Stein (2002) that small organizations are better than large ones in activities that require the processing of soft information in the context of bank lending to small firms. They find that large banks are less willing than small ones to lend to informationally difficult credits such as firms that do no keep formal financial records. They also find that large banks lend at a greater distance, interact more impersonally with their borrowers, have shorter and less exclusive relationships and do not alleviate credit constraints as effectively.

\section{Conclusion}

To the best of our knowledge, we are the first to find strong evidence that fund size erodes performance. We then move on to consider various explanations for why this might be the case. We find that this relationship is not driven by fund size being correlated with other observable fund characteristics nor due to any type of survivorship bias. Instead, we find that the effect of fund size on performance is most pronounced for 
funds that play small cap stocks. This suggests that liquidity is an important reason behind why size erodes performance. Moreover, we argue that organizational diseconomies related to hierarchy costs may also play a role in addition to liquidity in the documented diseconomies of scale. Consistent with this view, we find that funds that belong to large families do not perform worst than other funds and that small funds do better in their investments in local stocks than large funds.

Finally, our hypothesis suggests that how the fund is organized matters for whether or not scale affects performance. In other words, a crucial unobservable determinant of fund performance is the nature of the incentives inside the fund. ${ }^{14}$ More concretely, suppose that the organizational diseconomies are due to the adverse effects of a hierarchy on managerial effort. Then an optimal organizational structure is to limit managers to a small pot of money and let them manage it as they choose. With such an organizational structure, scale will not affect performance. This is exactly what happens at the family level and probably why performance does not depend on family size. Indeed, some fund families such as the Capitol Group do adopt such an organizational structure. However, it is not so easy for every fund family to adopt such an organizational form since managers will need to be compensated in other ways if their fund size is capped. ${ }^{15}$

\footnotetext{
${ }^{14}$ With this in mind, an interesting question is whether our hypothesis predicts that the ratio of fund size to number of people in the organization ought to be a determinant of fund performance, i.e. the higher this ratio, is the worst the performance? The answer is no since it depends on how the fund is organized. A fund with a very low ratio of fund size to number of people may do worse without the right organizational form. Interestingly, Prather and Middleton (2002) find that the number of people managing a fund does not seem to predict performance.

${ }^{15}$ Indeed, the Capitol Group follows a partnership track in which successful managers are given an ownership stake in the mutual fund organization. We thank Jack MacDonald for pointing this example out to us.
} 
Our findings are important for a couple of reasons beyond providing a better understanding of the importance of size in active money management. First, they may have normative implications for how funds are organized. Indeed, to this day, there are still contrasting views on how to go about dealing with growth in asset base. Some practitioners still see asset base growth as a good thing when accompanied with good past performance. Others have seen more clearly the importance of having the right organizational framework to deal with growth. Our findings provide additional evidence supporting the latter view.

Finally, our findings have relevance for the ongoing research into the question of Coase (1937) regarding the determinants of the boundaries of the firm. While an enormous amount of theoretical research has been done on this question, there has been far less empirical work. Our findings suggest that mutual funds may be an invaluable laboratory with which to study related issues in organization. Unlike most corporations, data on mutual funds are plentiful because of disclosure regulations and the tasks and performance of mutual funds are measurable. We plan to better refine our understanding of the nature of organizations in the future using this laboratory. 


\section{References}

Almazan, Andres, Keith C. Brown, Murray Carlson and David A. Chapman, 2001, Why constrain your mutual fund manager?, University of Texas Working Paper.

Becker, Stan and Greg Vaughan, 2001, Small is beautiful, Journal of Portfolio Management, summer, 9-17.

Berger, Allen N., Nathan H. Miller, Mitchell A. Petersen, Raghuram G. Rajan, and Jeremy C. Stein, 2002, Does function follow organizational form? Evidence from the lending practices of large and small banks, Harvard University Working Paper.

Berk, Jonathan and Richard C. Green, 2002, Mutual fund flows and performance in rational markets, U.C. Berkeley Working Paper.

Bolton, Patrick, and David S. Scharfstein, 1998, Corporate finance, the theory of the firm, and organizations, Journal of Economic Perspectives 12, 95-114.

Carhart, Mark M., 1997, On persistence in mutual fund performance, Journal of Finance, Vol. LII, 57-82.

Chen, Joseph, Harrison Hong and Jeremy C. Stein, 2002, Breadth of ownership and stock returns, Journal of Financial Economics, forthcoming.

Chevalier, Judith A., and Glenn D. Ellison, 1999, Career concerns of mutual fund managers, Quarterly Journal of Economics 114, 389-432.

Coase, Ronald H., 1937, The nature of the firm, Economica 4, 386-405.

Coval, Joshua D. and Tobias J. Moskowitz, 2001, The geography of investment: Informed trading and asset prices, Journal of Political Economy 4, 811-841.

Daniel, Kent, Mark Grinblatt, Sheridan Titman and Russ Wermers, 1997, Measuring mutual fund performance with characteristic-based benchmarks, Journal of Finance, 52, 1035-1058.

Elton, Edwin J., Martin J. Gruber and Christopher R. Blake, 2001, A first look at the accuracy of the CRSP Mutual Fund Database and a comparison of the CRSP and Morningstar Mutual Fund Databases, Journal of Finance, Vol. LVI, 2415-2430.

Falkenstein, Eric G., 1996, Preferences for stock characteristics as revealed by mutual fund portfolio holdings, Journal of Finance, 51, 111-135.

Fama, Eugene F. and French, Kenneth R., 1993, "Common Risk Factors in the Returns on Stocks and Bonds," Journal of Financial Economics 33, 3-56. 
Fama, Eugene F. and MacBeth, James D., 1973, "Risk, Return and Equilibrium: Empirical Tests," Journal of Political Economy 81, 607-636.

Fredman, Albert J. and Russ Wiles, 1998, How Mutual Funds Work, (Prentice Hall, New Jersey).

Grinblatt, Mark and Sheridan Titman, 1989, Mutual fund performance: An analysis of quarterly portfolio holdings, Journal of Business, 62, 393-416.

Grinblatt, Mark, Sheridan Titman and Russ Wermers, 1995, Momentum investment strategies, portfolio performance and herding: A study of mutual fund behavior, American Economic Review, 85, 1088-1105.

Grossman, Sanford J. and Oliver D. Hart, 1986, The costs and benefits of ownership: A theory of vertical and lateral integration, Journal of Political Economy 94, 691-719.

Gruber, Martin J., 1996, Another puzzle: The growth in actively managed mutual funds, Journal of Finance, Vol. LI, 783-810.

Hart, Oliver D., 1995, Firms, Contracts and Financial Structure (Oxford University Press, Oxford).

Hart, Oliver D. and John Moore, 1990, Property rights and the nature of the firm, Journal of Political Economy 98, 1119-1158.

Holmstrom, Bengt and John Roberts, 1998, The boundaries of the firm revisited, Journal of Economic Perspectives 12, 73-94.

Hong, Harrison, Jeffrey D. Kubik, and Amit Solomon, 2000, Security analysts' career concerns and the herding of earnings forecasts, RAND Journal of Economics 31, 121-144.

Hong, Harrison, Terence Lim and Jeremy C. Stein, 2000, Bad news travels slowly: Size, analyst coverage, and the profitability of momentum strategies, Journal of Finance, Vol. LV, 265-295.

IvKovic, Zoran, 2002, Spillovers in mutual fund families: Is blood thicker than water? University of Illinois Working Paper.

Jegadeesh, Narasimhan and Titman, Sheridan, 1993, "Returns to Buying Winners and Selling Losers: Implications for Stock Market Efficiency," Journal of Finance 48, 93-130.

Jensen, Michael C., 1968, The performance of mutual funds in the period 19451964, Journal of Finance, 50, 549-572. 
Lowenstein, Roger, 1997, Frightened funds: Is there a master in the house?, Wall Street Journal.

Malkiel, Burton G., 1995, returns from investing in equity mutual funds, 19711991, Journal of Finance, 50, 549-572.

Perold, Andre and Robert S. Salomon, 1991, The right amount of assets under management, Financial Analysts Journal, 47, 31-39.

Prather, Larry J. and Karen L. Middleton, 2002, Are N+1 heads better than one? The case of mutual fund managers, Journal of Economic Behavior and Organization, 47, 103-120.

Sharpe, William F., 1964, Capital asset prices: A theory of market equilibrium under conditions of risk, Journal of Finance 19, 425-42.

Sirri, Eric R and Peter Tufano, 1998, Costly search and mutual fund inflows, Journal of Finance 53, 1589-1622.

Stein, Jeremy C., 2002, Information production and capital allocation: Decentralized vs. hierarchial firms, Journal of Finance, forthcoming.

Wermers, Russ, 2000, Mutual fund performance: An empirical decomposition into stock-picking talent, style, transactions costs and expenses, Journal of Finance, Vol. LV, 1655-1695.

Williamson, Oliver E., 1975, Markets and Hierarchies: Analysis and Antitrust Implications, (Collier MacMillan, New York).

Williamson, Oliver E., 1988, Corporate finance and corporate governance, Journal of Finance, 43, 567-591.

Zheng, Lu, 1999, Is money smart? A study of mutual fund investors' fund selection ability, Journal of Finance, Vol. LIV, 901-933. 


\section{Table 1: Summary Statistics}

This table shows the summary statistics of the characteristics of the mutual funds used in this study. The number of funds is the number of mutual funds that meets our selection criteria for being a domestic active mutual fund in each month. TNA is the total net assets of funds in millions of dollars. Expense ratio is total annual management and administrative expenses divided by average TNA. Turnover is the fund turnover reported by CRSP, which is the minimum of aggregate purchases and sales of securities divided by the average TNA. Total load is the total front-end, deferred and rear-end charges as a percentage of new investments. Fund age is the number of years since the organization of the mutual fund. TNA is reported monthly. All other fund characteristics are reported one a year. The sample is from December 1962 to December 1999. Panel A reports the time-series averages of monthly cross-sectional averages and monthly cross-sectional standard deviations of mutual fund characteristics. The time-series averages of monthly cross-sectional standard deviations are shown in brackets. Panel B reports the time-series averages of the cross-sectional correlations between mutual fund characteristics.

Panel A: Time-series averages of cross-sectional averages and standard deviations.

\begin{tabular}{|c|c|c|c|c|c|c|c|}
\hline \multirow{2}{*}{ Sample } & \multicolumn{5}{|c|}{ Mutual Fund Size Quintile } & \multirow{2}{*}{$\begin{array}{l}\text { All } \\
\text { Funds }\end{array}$} & \multirow{2}{*}{$\begin{array}{l}\text { Quintiles } \\
2-5\end{array}$} \\
\hline & 1 & 2 & 3 & 4 & 5 & & \\
\hline $\begin{array}{l}\text { Number of } \\
\text { Funds }\end{array}$ & 127.2 & 126.8 & 126.8 & 126.8 & 126.3 & 633.8 & 506.7 \\
\hline $\begin{array}{l}\text { TNA } \\
\text { (\$ million) }\end{array}$ & $\begin{array}{c}6.1 \\
{[3.9]}\end{array}$ & $\begin{array}{l}26.2 \\
{[8.0]}\end{array}$ & $\begin{array}{c}68.0 \\
{[17.5]}\end{array}$ & $\begin{array}{l}178.9 \\
{[57.6]}\end{array}$ & $\begin{array}{c}1153.8 \\
{[1653.5]}\end{array}$ & $\begin{array}{c}285.6 \\
{[866.9]}\end{array}$ & $\begin{array}{c}355.9 \\
{[955.9]}\end{array}$ \\
\hline $\begin{array}{l}\text { LogTNA } \\
\text { (\$ million) }\end{array}$ & $\begin{array}{c}1.35 \\
{[0.91]}\end{array}$ & $\begin{array}{c}3.07 \\
{[0.32]}\end{array}$ & $\begin{array}{c}4.05 \\
{[0.26]}\end{array}$ & $\begin{array}{c}5.00 \\
{[0.32]}\end{array}$ & $\begin{array}{c}6.47 \\
{[0.73]} \\
\end{array}$ & $\begin{array}{c}3.98 \\
{[1.83]}\end{array}$ & $\begin{array}{c}4.65 \\
{[1.34]}\end{array}$ \\
\hline $\begin{array}{r}\text { Expense Ratio } \\
\text { (\% per year) }\end{array}$ & $\begin{array}{c}1.34 \\
{[1.02]}\end{array}$ & $\begin{array}{r}1.09 \\
{[0.56]}\end{array}$ & $\begin{array}{c}0.94 \\
{[0.43]}\end{array}$ & $\begin{array}{c}0.85 \\
{[0.35]}\end{array}$ & $\begin{array}{c}0.67 \\
{[0.30]}\end{array}$ & $\begin{array}{c}0.98 \\
{[0.65]}\end{array}$ & $\begin{array}{c}0.89 \\
{[0.46]}\end{array}$ \\
\hline $\begin{array}{l}\text { Turnover } \\
\text { (\% per year) }\end{array}$ & $\begin{array}{c}46.9 \\
{[81.3]}\end{array}$ & $\begin{array}{c}57.7 \\
{[72.3]}\end{array}$ & $\begin{array}{c}61.6 \\
{[68.2]}\end{array}$ & $\begin{array}{c}61.3 \\
{[63.0]}\end{array}$ & $\begin{array}{c}51.5 \\
{[53.8]}\end{array}$ & $\begin{array}{c}55.8 \\
{[70.8]}\end{array}$ & $\begin{array}{c}58.0 \\
{[66.2]}\end{array}$ \\
\hline $\begin{array}{l}\text { Total Load } \\
\text { (\%) }\end{array}$ & $\begin{array}{c}3.51 \\
{[3.40]}\end{array}$ & $\begin{array}{c}4.29 \\
{[3.37]}\end{array}$ & $\begin{array}{c}4.43 \\
{[3.40]}\end{array}$ & $\begin{array}{c}4.67 \\
{[3.42]}\end{array}$ & $\begin{array}{c}5.37 \\
{[2.87]}\end{array}$ & $\begin{array}{c}4.45 \\
{[3.40]}\end{array}$ & $\begin{array}{c}4.69 \\
{[3.35]}\end{array}$ \\
\hline $\begin{array}{c}\text { Fund Age } \\
\text { (years) }\end{array}$ & $\begin{array}{c}9.6 \\
{[9.0]}\end{array}$ & $\begin{array}{c}13.1 \\
{[11.2]}\end{array}$ & $\begin{array}{c}15.7 \\
{[13.1]}\end{array}$ & $\begin{array}{c}19.2 \\
{[14.5]}\end{array}$ & $\begin{array}{c}25.7 \\
{[14.9]}\end{array}$ & $\begin{array}{c}16.6 \\
{[14.0]}\end{array}$ & $\begin{array}{c}18.4 \\
{[14.4]}\end{array}$ \\
\hline
\end{tabular}


Panel B: Time-series averages of (monthly) correlations between fund characteristics. [Using all funds]

\begin{tabular}{lrrrrrr}
\hline & TNA & Log TNA & Exp. Ratio & Turnover & Tot. Load & Fund Age \\
\hline TNA & 1.00 & 0.57 & -0.21 & -0.06 & 0.10 & 0.27 \\
Log TNA & & 1.00 & -0.37 & 0.03 & 0.19 & 0.41 \\
Exp. Ratio & & & 1.00 & 0.15 & -0.05 & -0.18 \\
Turnover & & & & 1.00 & 0.05 & -0.02 \\
Total Load & & & & & 1.00 & 0.19 \\
Fund Age & & & & & & 1.00 \\
\hline
\end{tabular}

Panel C: Time-series averages of (monthly) correlations between fund characteristics. [Excluding smallest $20 \%$ of funds]

\begin{tabular}{lrrrrrr}
\hline & TNA & Log TNA & Exp. Ratio & Turnover & Tot. Load & Fund Age \\
\hline TNA & 1.00 & 0.68 & -0.26 & -0.09 & 0.09 & 0.24 \\
Log TNA & & 1.00 & -0.38 & -0.07 & 0.13 & 0.35 \\
Exp. Ratio & & & 1.00 & 0.24 & 0.01 & -0.22 \\
Turnover & & & & 1.00 & 0.03 & -0.07 \\
Total Load & & & & & 1.00 & 0.17 \\
Fund Age & & & & & & 1.00 \\
\hline
\end{tabular}




\section{Table 2: Summary Statistics for Benchmark Portfolios}

This table reports the summary statistics for the factors and benchmark portfolios. Panel A reports the summary statistics of the factors. VWRF is the rate of return on the CRSP valueweighted stock index in excess of the one-month Treasury rate. SMB is the return on the factor-mimicking portfolio for the size factor from Fama and French (1993). HML is the return on the factor-mimicking portfolio for the book-to-market factor from Fama and French (1993). MOM12 is the return on the factor-mimicking portfolio for the momentum factor. Panels B and C report the summary statistics of mutual fund portfolios sorted by past TNA. Equal-weighted portfolios of mutual funds are formed at the beginning of each month based on the decile rankings of their previous month TNA. The portfolios are held until the end of the month. Panel B reports the average market-adjusted monthly return of the benchmark portfolios and the standard deviation of unadjusted monthly returns. Panel B also reports the alphas and the betas from CAPM. Panel $\mathrm{C}$ reports the alphas and the factor-loadings from Fama and French 3-factor model and the 4-factor model. The sample period is from December 1962 to December 1999.

Panel A: Summary statistics of factor-mimicking portfolios.

\begin{tabular}{lccrrrr}
\hline \multirow{2}{*}{ Factor } & Mean & SD of & \multicolumn{4}{c}{ Cross-correlations } \\
\cline { 5 - 7 } & Return & Return & VWRF & SMB & HML & MOM12 \\
\hline VWRF & $0.58 \%$ & $4.37 \%$ & 1.00 & 0.32 & -0.39 & -0.02 \\
SMB & $0.17 \%$ & $2.90 \%$ & & 1.00 & -0.16 & -0.30 \\
HML & $0.34 \%$ & $2.63 \%$ & & & 1.00 & -0.15 \\
MOM12 & $0.96 \%$ & $3.88 \%$ & & & & 1.00 \\
\hline
\end{tabular}

Panel B: Summary statistics and CAPM loadings of mutual fund portfolios sorted by past TNA.

\begin{tabular}{lrrrr}
\hline & Mean Market- & Std Dev of & \multicolumn{2}{c}{ CAPM } \\
\cline { 4 - 5 } Portfolio & Adjusted Return & Total Return & Alpha & VWRF \\
\hline 1 (small) & $-0.05 \%$ & $3.94 \%$ & $0.02 \%$ & 0.88 \\
2 & $-0.07 \%$ & $4.05 \%$ & $-0.01 \%$ & 0.91 \\
3 & $-0.06 \%$ & $4.15 \%$ & $-0.02 \%$ & 0.93 \\
4 & $-0.12 \%$ & $4.07 \%$ & $-0.08 \%$ & 0.92 \\
5 (large) & $-0.12 \%$ & $4.01 \%$ & $-0.07 \%$ & 0.91 \\
\hline
\end{tabular}

Panel C: Factor loadings from the 3-factor model and from the 4-factor model of mutual fund portfolios sorted by past TNA.

\begin{tabular}{lrrrrrrrrr}
\hline & \multicolumn{3}{c}{ 3-Factor Model } & & \multicolumn{4}{c}{ 4-Factor Model } & \\
\cline { 2 - 4 } \multicolumn{1}{c}{ Portfolio } & Alpha & VWRF & SMB & HML & Alpha & VWRF & SMB & HML & MOM12 \\
\hline 1 (low) & $-0.01 \%$ & 0.83 & 0.29 & 0.04 & $-0.04 \%$ & 0.83 & 0.30 & 0.05 & 0.03 \\
2 & $-0.02 \%$ & 0.85 & 0.26 & -0.01 & $-0.08 \%$ & 0.85 & 0.29 & 0.01 & 0.05 \\
3 & $0.00 \%$ & 0.87 & 0.22 & -0.06 & $-0.08 \%$ & 0.87 & 0.25 & -0.04 & 0.06 \\
4 & $-0.05 \%$ & 0.87 & 0.17 & -0.06 & $-0.12 \%$ & 0.87 & 0.20 & -0.04 & 0.06 \\
5 (large) & $-0.05 \%$ & 0.88 & 0.07 & -0.06 & $-0.10 \%$ & 0.88 & 0.09 & -0.05 & 0.05 \\
\hline
\end{tabular}




\section{Table 3: Baseline Effect of Fund Size on Performance}

This table shows the relationship between risk-adjusted mutual fund returns and the size of the mutual fund at the beginning of the period. Panel A shows this relationship using mutual fund returns calculated before deducting operating expenses (gross fund returns). Panel B shows this relationship using mutual fund returns calculated net of operating expenses (net fund returns). Mutual funds are first sorted into quintiles based on their beginning of the period TNAs. One-month mutual fund returns are calculated in excess of the market model, the CAPM, the Fama-French 3-Factor model, and the 4-Factor model. Returns are cumulated (buy-hold) over the next 12 months based on the one-month risk-adjusted mutual fund returns. This table shows the time-series averages of the cross-sectional average cumulative risk-adjusted returns within each size quintile. The brackets show the time-series averages of the cross-sectional standard deviations of fund returns. The last column shows the differences in the averages with serial-correlation adjusted t-statistics in parentheses.

Panel A: Using gross fund returns

\begin{tabular}{lccccccc}
\hline & \multicolumn{6}{c}{ Mutual Fund Size Quintile } & Difference \\
\cline { 2 - 7 } & 1 & 2 & 3 & 4 & 5 & $1-5$ \\
\hline \multirow{2}{*}{ Market-Adj } & $1.13 \%$ & $0.69 \%$ & $0.22 \%$ & $-0.53 \%$ & $-0.72 \%$ & $1.85 \%$ \\
& {$[12.56 \%]$} & {$[10.87 \%]$} & {$[10.43 \%]$} & {$[9.45 \%]$} & {$[7.69 \%]$} & $(5.85)$ \\
\hline \multirow{2}{*}{ CAPM } & $1.91 \%$ & $1.29 \%$ & $0.68 \%$ & $0.00 \%$ & $-0.16 \%$ & $2.07 \%$ \\
& {$[12.63 \%]$} & {$[10.91 \%]$} & {$[10.47 \%]$} & {$[9.49 \%]$} & {$[7.72 \%]$} & $(6.57)$ \\
\hline \multirow{2}{*}{ 3-Factor } & $1.54 \%$ & $1.23 \%$ & $0.89 \%$ & $0.29 \%$ & $0.18 \%$ & $1.36 \%$ \\
& {$[12.61 \%]$} & {$[10.94 \%]$} & {$[10.50 \%]$} & {$[9.52 \%]$} & {$[7.75 \%]$} & $(6.39)$ \\
\hline \multirow{2}{*}{ 4-Factor } & $1.16 \%$ & $0.50 \%$ & $0.03 \%$ & $-0.50 \%$ & $-0.45 \%$ & $1.62 \%$ \\
& {$[12.56 \%]$} & {$[10.86 \%]$} & {$[10.42 \%]$} & {$[9.46 \%]$} & {$[7.71 \%]$} & $(7.53)$ \\
\hline \multirow{2}{*}{ No. of months } & 433 & 433 & 433 & 433 & 433 & 433 \\
\hline
\end{tabular}

Panel B: Using net fund returns

\begin{tabular}{|c|c|c|c|c|c|c|}
\hline & \multicolumn{5}{|c|}{ Mutual Fund Size Quintile } & \multirow{2}{*}{$\begin{array}{c}\text { Difference } \\
1-5\end{array}$} \\
\hline & 1 & 2 & 3 & 4 & 5 & \\
\hline Market-Adj & $\begin{array}{c}-0.32 \% \\
{[12.39 \%]}\end{array}$ & $\begin{array}{c}-0.45 \% \\
{[10.76 \%]}\end{array}$ & $\begin{array}{c}-0.74 \% \\
{[10.33 \%]}\end{array}$ & $\begin{array}{c}-1.38 \% \\
{[9.39 \%]}\end{array}$ & $\begin{array}{c}-1.40 \% \\
{[7.65 \%]}\end{array}$ & $\begin{array}{l}1.08 \% \\
(3.42)\end{array}$ \\
\hline CAPM & $\begin{array}{c}0.45 \% \\
{[12.46 \%]}\end{array}$ & $\begin{array}{c}0.14 \% \\
{[10.80 \%]}\end{array}$ & $\begin{array}{c}-0.29 \% \\
{[10.37 \%]}\end{array}$ & $\begin{array}{c}-0.85 \% \\
{[9.43 \%]}\end{array}$ & $\begin{array}{c}-0.83 \% \\
{[7.68 \%]}\end{array}$ & $\begin{array}{l}1.28 \% \\
(4.11)\end{array}$ \\
\hline 3-Factor & $\begin{array}{c}0.09 \% \\
{[12.45 \%]}\end{array}$ & $\begin{array}{c}0.09 \% \\
{[10.83 \%]}\end{array}$ & $\begin{array}{c}-0.08 \% \\
{[10.40 \%]}\end{array}$ & $\begin{array}{l}-0.57 \% \\
{[9.46 \%]}\end{array}$ & $\begin{array}{c}-0.50 \% \\
{[7.71 \%]}\end{array}$ & $\begin{array}{l}0.58 \% \\
(2.73)\end{array}$ \\
\hline 4-Factor & $\begin{array}{c}-0.29 \% \\
{[12.39 \%]}\end{array}$ & $\begin{array}{c}-0.64 \% \\
{[10.75 \%]}\end{array}$ & $\begin{array}{c}-0.93 \% \\
{[10.32 \%]}\end{array}$ & $\begin{array}{c}-1.36 \% \\
{[9.40 \%]}\end{array}$ & $\begin{array}{l}-1.13 \% \\
{[7.67 \%]}\end{array}$ & $\begin{array}{l}0.84 \% \\
(3.90) \\
\end{array}$ \\
\hline No. of months & 433 & 433 & 433 & 433 & 433 & 433 \\
\hline
\end{tabular}




\section{Table 4: The Effect of Fund Size on Performance Controlling for Other Fund Characteristics}

This table shows the Fama-Macbeth (1973) regression estimates of future cumulative riskadjusted mutual fund returns on beginning of the period mutual fund characteristics. Onemonth mutual fund returns are calculated in excess of the market model, the CAPM, the Fama-French 3-Factor model, and the 4-Factor model. The dependent variable in each case is the cumulative (buy-hold) 12-months ahead future returns based on the one-month riskadjusted mutual fund returns. The independent variables are all measured at the beginning of the period. The t-statistics are adjusted for serial correlations and are shown in parentheses. The last row shows the time-series averages of the $\mathrm{R}^{2}$, s from the Fama-Macbeth (1973) regressions at each period.

Panel A uses all mutual fund returns calculated before deducting operating expenses (gross fund returns). Panel B uses all mutual fund returns calculated net of operating expenses (net fund returns). Panel $\mathrm{C}$ uses gross fund returns, excluding mutual funds in the lowest fund size quintile. Panel D uses net fund returns, excluding mutual funds in the lowest fund size quintile.

Panel A: Dependent variable is 4-quarter gross fund returns (all fund size quintiles 1-5)

\begin{tabular}{lcccc}
\hline & Market-Adj & Beta-Adj & 3-Factor & 4-Factor \\
\hline \multirow{2}{*}{ Intercept } & 1.119 & 1.867 & 1.562 & 1.059 \\
& $(2.59)$ & $(4.53)$ & $(4.76)$ & $(3.24)$ \\
\hline \multirow{2}{*}{ LogTNA $_{\mathrm{i}, \mathrm{t}-1}$} & -0.254 & -0.292 & -0.156 & -0.204 \\
& $(3.91)$ & $(4.74)$ & $(2.51)$ & $(3.30)$ \\
\hline \multirow{2}{*}{ Turnover $_{\mathrm{i}, \mathrm{t}-1}$} & 0.001 & 0.001 & 0.001 & 0.001 \\
& $(0.80)$ & $(0.79)$ & $(0.72)$ & $(0.57)$ \\
\hline \multirow{2}{*}{ Age $_{\mathrm{i}, \mathrm{t}-1}$} & -0.029 & -0.029 & -0.029 & -0.028 \\
\multirow{2}{*}{ Expense Ratio $_{\mathrm{i}, \mathrm{t}-1}$} & $(2.83)$ & $(2.85)$ & $(2.89)$ & $(2.82)$ \\
& 0.192 & 0.188 & 0.156 & 0.153 \\
\multirow{2}{*}{ Total Load $_{\mathrm{i}, \mathrm{t}-1}$} & $(0.73)$ & $(0.71)$ & $(0.61)$ & $(0.61)$ \\
\hline \multirow{2}{*}{ No. of months } & 0.050 & 0.049 & 0.048 & 0.048 \\
\hline Average R & $(3.24)$ & $(3.20)$ & $(3.14)$ & $(3.14)$ \\
\hline
\end{tabular}


Panel B: Dependent variable is 4-quarter net fund returns (all fund size quintiles 1-5)

\begin{tabular}{|c|c|c|c|c|}
\hline & Market-Adj & Beta-Adj & 3-Factor & 4-Factor \\
\hline \multirow{2}{*}{ Intercept } & 0.373 & 1.118 & 0.816 & 0.313 \\
\hline & $(0.88)$ & $(2.75)$ & $(2.49)$ & $(0.96)$ \\
\hline \multirow{2}{*}{$\operatorname{LogTNA}_{i, t-1}$} & -0.182 & -0.220 & -0.085 & -0.133 \\
\hline & (2.84) & $(3.60)$ & $(1.38)$ & $(2.16)$ \\
\hline \multirow{2}{*}{ Turnover $_{\mathrm{i}, \mathrm{t}-1}$} & 0.001 & 0.001 & 0.001 & 0.001 \\
\hline & $(0.66)$ & $(0.65)$ & $(0.58)$ & $(0.43)$ \\
\hline \multirow{2}{*}{$\operatorname{Age}_{i, t-1}$} & -0.027 & -0.027 & -0.027 & -0.026 \\
\hline & $(2.66)$ & $(2.68)$ & $(2.71)$ & $(2.65)$ \\
\hline \multirow{2}{*}{ Expense Ratio $_{\mathrm{i}, \mathrm{t}-1}$} & -0.356 & -0.364 & -0.397 & -0.397 \\
\hline & (1.34) & $(1.36)$ & $(1.53)$ & (1.57) \\
\hline \multirow{2}{*}{ Total $\operatorname{Load}_{\mathrm{i}, \mathrm{t}-1}$} & 0.049 & 0.049 & 0.048 & 0.048 \\
\hline & $(3.29)$ & $(3.25)$ & (3.19) & $(3.20)$ \\
\hline No. of months & 433 & 433 & 433 & 433 \\
\hline Average $\mathrm{R}^{2}$ & $7.07 \%$ & $7.05 \%$ & $6.20 \%$ & $6.26 \%$ \\
\hline
\end{tabular}

Panel C: Dependent variable is 4-quarter gross fund returns (only fund size quintiles 2-5)

\begin{tabular}{|c|c|c|c|c|}
\hline & Market-Adj & Beta-Adj & 3-Factor & 4-Factor \\
\hline \multirow{2}{*}{ Intercept } & 0.416 & 0.960 & 0.897 & 0.000 \\
\hline & $(0.97)$ & $(2.36)$ & $(1.91)$ & $(0.00)$ \\
\hline \multirow{2}{*}{$\log \mathrm{TNA}_{\mathrm{i}, \mathrm{t}-1}$} & -0.243 & -0.243 & -0.150 & -0.120 \\
\hline & (4.14) & (4.13) & $(2.24)$ & $(1.80)$ \\
\hline \multirow{2}{*}{ Turnover $_{\mathrm{i}, \mathrm{t}-1}$} & 0.003 & 0.003 & 0.003 & 0.003 \\
\hline & $(2.01)$ & $(2.02)$ & $(2.01)$ & (1.98) \\
\hline \multirow{2}{*}{$\operatorname{Age}_{i, t-1}$} & -0.017 & -0.017 & -0.017 & -0.017 \\
\hline & $(1.75)$ & (1.78) & $(1.76)$ & (1.74) \\
\hline \multirow{2}{*}{ Expense Ratio $_{\mathrm{i}, \mathrm{t}-1}$} & 0.791 & 0.786 & 0.729 & 0.723 \\
\hline & $(1.88)$ & $(1.87)$ & $(1.77)$ & (1.77) \\
\hline \multirow{2}{*}{ Total $\operatorname{Load}_{\mathrm{i}, \mathrm{t}-1}$} & 0.041 & 0.042 & 0.042 & 0.042 \\
\hline & $(2.61)$ & $(2.63)$ & $(2.62)$ & $(2.65)$ \\
\hline No. of months & 433 & 433 & 433 & 433 \\
\hline Average $\mathrm{R}^{2}$ & $8.27 \%$ & $8.26 \%$ & $7.29 \%$ & $7.26 \%$ \\
\hline
\end{tabular}


Panel D: Dependent variable is 4-quarter net fund returns (only fund size quintiles 2-5)

\begin{tabular}{lcccc}
\hline & Market-Adj & Beta-Adj & 3-Factor & 4-Factor \\
\hline \multirow{2}{*}{ Intercept } & -0.149 & 0.393 & 0.328 & -0.566 \\
& $(0.36)$ & $(0.99)$ & $(0.71)$ & $(1.21)$ \\
\hline \multirow{2}{*}{ LogTNA $_{\mathrm{i}, \mathrm{t}-1}$} & -0.194 & -0.193 & -0.101 & -0.071 \\
& $(3.35)$ & $(3.34)$ & $(1.52)$ & $(1.07)$ \\
\hline \multirow{2}{*}{ Turnover $_{\mathrm{i}, \mathrm{t}-1}$} & 0.003 & 0.003 & 0.003 & 0.003 \\
& $(1.86)$ & $(1.87)$ & $(1.86)$ & $(1.83)$ \\
\hline \multirow{2}{*}{ Age $_{\mathrm{i}, \mathrm{t}-1}$} & -0.015 & -0.015 & -0.015 & -0.015 \\
& $(1.55)$ & $(1.58)$ & $(1.56)$ & $(1.54)$ \\
\multirow{2}{*}{ Expense Ratio $_{\mathrm{i}, \mathrm{t}-1}$} & 0.152 & 0.143 & 0.086 & 0.084 \\
& $(0.36)$ & $(0.34)$ & $(0.21)$ & $(0.21)$ \\
\hline \multirow{2}{*}{ Total Load $_{\mathrm{i}, \mathrm{t}-1}$} & 0.038 & 0.039 & 0.039 & 0.039 \\
& $(2.45)$ & $(2.48)$ & $(2.46)$ & $(2.49)$ \\
\hline No. of months & 433 & 433 & 433 & 433 \\
\hline Average R & $7.76 \%$ & $7.76 \%$ & $6.85 \%$ & $6.83 \%$ \\
\hline
\end{tabular}




\section{Table 5: Effect of Fund Size on Performance by Fund Style}

Panels A and B show the Fama-Macbeth regression estimates of future cumulative riskadjusted mutual fund returns on beginning of the period mutual fund characteristics. The independent variables are all measured at the beginning of the period. $\operatorname{Ind}_{\{\text {not SCG }}$ is a dummy variable which equals one if the self-reported fund style is not Small Cap Growth and zero otherwise. The t-statistics are adjusted for serial correlations and are shown in parenthesis.

Panel A: Gross fund returns, only fund size quintiles 2-5

\begin{tabular}{|c|c|c|c|c|}
\hline & Market-Adj & Beta-Adj & 3-Factor & 4-Factor \\
\hline \multirow{2}{*}{ Intercept } & 4.895 & 5.472 & 5.337 & 4.411 \\
\hline & $(3.80)$ & $(4.29)$ & $(4.72)$ & $(3.95)$ \\
\hline \multirow{2}{*}{$\operatorname{Ind}_{\{\text {not SCG }\}}$} & -4.696 & -4.731 & -4.661 & -4.632 \\
\hline & $(3.83)$ & $(3.86)$ & $(3.75)$ & $(3.76)$ \\
\hline \multirow{2}{*}{$\operatorname{LogTNA}_{\mathrm{i}, \mathrm{t}-1}$} & -0.784 & -0.791 & -0.693 & -0.662 \\
\hline & $(3.17)$ & $(3.20)$ & $(2.81)$ & $(2.70)$ \\
\hline \multirow{2}{*}{$\operatorname{LogTNA}_{\mathrm{i}, \mathrm{t}-1} \operatorname{Ind}_{\{\text {not SCG }\}}$} & 0.570 & 0.578 & 0.573 & 0.573 \\
\hline & $(2.50)$ & $(2.54)$ & $(2.49)$ & $(2.51)$ \\
\hline \multirow{2}{*}{ Turnover $_{i, t-1}$} & 0.003 & 0.003 & 0.003 & 0.003 \\
\hline & $(1.88)$ & (1.89) & $(1.88)$ & $(1.85)$ \\
\hline \multirow{2}{*}{ Age $_{i, t-1}$} & -0.017 & -0.017 & -0.017 & -0.017 \\
\hline & $(1.93)$ & (1.97) & $(1.95)$ & (1.94) \\
\hline \multirow{2}{*}{ Expense Ratio $_{i, t-1}$} & 0.694 & 0.689 & 0.640 & 0.633 \\
\hline & $(1.87)$ & $(1.85)$ & $(1.76)$ & $(1.77)$ \\
\hline \multirow{2}{*}{ Total Load } & 0.054 & 0.054 & 0.053 & 0.054 \\
\hline & $(3.22)$ & $(3.23)$ & (3.19) & $(3.21)$ \\
\hline No. of months & 433 & 433 & 433 & 433 \\
\hline
\end{tabular}


Panel B: Net fund returns, only fund size quintiles 2-5

\begin{tabular}{|c|c|c|c|c|}
\hline & Market-Adj & Beta-Adj & 3-Factor & 4-Factor \\
\hline \multirow{2}{*}{ Intercept } & 4.273 & 4.849 & 4.712 & 3.789 \\
\hline & $(3.32)$ & $(3.81)$ & $(4.17)$ & (3.39) \\
\hline \multirow{2}{*}{$\operatorname{Ind}_{\{\text {not SCG }\}}$} & -4.634 & -4.669 & -4.599 & -4.569 \\
\hline & $(3.78)$ & $(3.81)$ & $(3.71)$ & $(3.71)$ \\
\hline \multirow{2}{*}{$\operatorname{LogTNA}_{i, t-1}$} & -0.724 & -0.731 & -0.633 & -0.603 \\
\hline & $(2.92)$ & $(2.96)$ & $(2.56)$ & $(2.46)$ \\
\hline \multirow{2}{*}{$\log \operatorname{TNA}_{\mathrm{i}, \mathrm{t}-1} \operatorname{Ind}_{\{\text {not SCG }\}}$} & 0.559 & 0.567 & 0.562 & 0.562 \\
\hline & $(2.46)$ & $(2.49)$ & $(2.44)$ & $(2.46)$ \\
\hline \multirow{2}{*}{ Turnover $_{\mathrm{i}, \mathrm{t}-1}$} & 0.003 & 0.003 & 0.003 & 0.003 \\
\hline & $(1.73)$ & (1.74) & $(1.73)$ & $(1.70)$ \\
\hline \multirow{2}{*}{ Age $_{i, t-1}$} & -0.015 & -0.016 & -0.016 & -0.015 \\
\hline & $(1.72)$ & $(1.76)$ & $(1.74)$ & $(1.73)$ \\
\hline \multirow{2}{*}{ Expense Ratio ${ }_{i, t-1}$} & 0.056 & 0.047 & -0.003 & -0.005 \\
\hline & $(0.15)$ & $(0.13)$ & $(0.01)$ & $(0.02)$ \\
\hline \multirow{2}{*}{ Total $\operatorname{Load}_{\mathrm{i}, \mathrm{t}-1}$} & 0.051 & 0.051 & 0.050 & 0.051 \\
\hline & $(3.08)$ & $(3.09)$ & $(3.05)$ & $(3.07)$ \\
\hline No. of months & 433 & 433 & 433 & 433 \\
\hline
\end{tabular}




\section{Table 6: Effect of Family Size and Fund Size on Performance}

Panels A and B show the Fama-Macbeth regression estimates of future cumulative riskadjusted mutual fund returns on beginning of the period mutual fund characteristics. The independent variables are all measured at the beginning of the period. LogFamSize is the log of the size of the family that the fund belongs to, where family size is the cumulative TNA of funds belonging to the family. The t-statistics are adjusted for serial correlations and are shown in parenthesis.

Panel A: Gross fund returns, only fund size quintiles 2-5

\begin{tabular}{lcccc}
\hline & Market-Adj & Beta-Adj & 3-Factor & 4-Factor \\
\hline \multirow{2}{*}{ Intercept } & 1.921 & 2.750 & 2.214 & 1.741 \\
& $(2.06)$ & $(3.09)$ & $(2.18)$ & $(1.72)$ \\
\hline \multirow{2}{*}{ LogFamSize $_{\mathrm{i}, \mathrm{t}-1}$} & -0.051 & -0.089 & -0.018 & -0.079 \\
& $(0.47)$ & $(0.85)$ & $(0.17)$ & $(0.78)$ \\
\hline \multirow{2}{*}{ LogTNA $_{\mathrm{i}, \mathrm{t}-1}$} & -0.850 & -0.920 & -0.691 & -0.772 \\
& $(3.52)$ & $(3.90)$ & $(2.83)$ & $(3.20)$ \\
\hline LogTNA $_{\mathrm{i}, \mathrm{t}-1}$ & 0.057 & 0.066 & 0.046 & 0.062 \\
LogFamSize $_{\mathrm{i}, \mathrm{t}-1}$ & $(1.96)$ & $(2.33)$ & $(1.66)$ & $(2.27)$ \\
\hline \multirow{2}{*}{ Turnover $_{\mathrm{i}, \mathrm{t}-1}$} & 0.003 & 0.003 & 0.003 & 0.003 \\
& $(1.80)$ & $(1.80)$ & $(1.79)$ & $(1.79)$ \\
\multirow{2}{*}{ Age $\mathrm{I}, \mathrm{t}-1$} & -0.015 & -0.015 & -0.016 & -0.015 \\
& $(1.55)$ & $(1.58)$ & $(1.58)$ & $(1.54)$ \\
\hline \multirow{2}{*}{ Expense Ratio } & 0.809 & 0.804 & 0.752 & 0.744 \\
& $(1.91)$ & $(1.90)$ & $(1.82)$ & $(1.82)$ \\
\hline \multirow{2}{*}{ Total Load } & 0.024 & 0.024 & 0.025 & 0.025 \\
& $(1.43)$ & $(1.43)$ & $(1.48)$ & $(1.46)$ \\
\hline No. of months & 433 & 433 & 433 & 433 \\
\hline
\end{tabular}


Panel B: Net fund returns, only fund size quintiles 2-5

\begin{tabular}{lcccc}
\hline & Market-Adj & Beta-Adj & 3-Factor & 4-Factor \\
\hline \multirow{2}{*}{ Intercept } & 0.975 & 1.790 & 1.258 & 0.759 \\
& $(1.01)$ & $(1.95)$ & $(1.20)$ & $(0.72)$ \\
\hline \multirow{2}{*}{ LogFamSize $_{\mathrm{i}, \mathrm{t}-1}$} & -0.022 & -0.058 & 0.011 & -0.046 \\
& $(0.20)$ & $(0.53)$ & $(0.10)$ & $(0.43)$ \\
\hline \multirow{2}{*}{ LogTNA $_{\mathrm{i}, \mathrm{t}-1}$} & -0.660 & -0.726 & -0.497 & -0.571 \\
& $(2.61)$ & $(2.94)$ & $(1.93)$ & $(2.25)$ \\
\hline LogTNA $_{\mathrm{i}, \mathrm{t}-1}$ & 0.038 & 0.047 & 0.027 & 0.042 \\
LogFamSize $_{\mathrm{i}, \mathrm{t}-1}$ & $(1.25)$ & $(1.57)$ & $(0.93)$ & $(1.45)$ \\
\hline \multirow{2}{*}{ Turnover $_{\mathrm{i}, \mathrm{t}-1}$} & 0.003 & 0.003 & 0.003 & 0.003 \\
& $(1.68)$ & $(1.68)$ & $(1.66)$ & $(1.66)$ \\
\multirow{2}{*}{ Age $\mathrm{I}, \mathrm{t}-1$} & -0.012 & -0.012 & -0.013 & -0.012 \\
& $(1.25)$ & $(1.27)$ & $(1.28)$ & $(1.24)$ \\
\hline \multirow{2}{*}{ Expense Ratio } & 0.209 & 0.202 & 0.149 & 0.146 \\
& $(0.49)$ & $(0.47)$ & $(0.36)$ & $(0.35)$ \\
\hline \multirow{2}{*}{ Total Load } & 0.025 & 0.025 & 0.026 & 0.026 \\
& $(1.52)$ & $(1.52)$ & $(1.57)$ & $(1.56)$ \\
\hline No. of months & 433 & 433 & 433 & 433 \\
\hline
\end{tabular}




\section{Table 7: The Effect of Fund Size on the Performance of Investments in Local Stocks}

The dependent variable is the 4-quarter return to fund investments in local stocks. Small Fund equals one if a fund's size is in the bottom $10 \%$ of the fund size distribution and zero otherwise. Small Cap Fund equals one if a fund's Daniel, Grinblatt, Titman and Wermers (1997) small cap style score is in the bottom $10 \%$ across funds. Momentum Effects and Book to Market Effects control for other differences in fund styles. Data is from the end of September 1997. Robust standard errors are reported in parentheses.

\begin{tabular}{lcccc}
\hline & $(1)$ & $(2)$ & $(3)$ & $(4)$ \\
\hline Small Fund & .0258 & .0143 & .0150 & .0116 \\
& $(.0141)$ & $(.0152)$ & $(.0152)$ & $(.0153)$ \\
Small Cap Fund & .1190 & .1078 & .1079 & .1065 \\
& $(.0145)$ & $(.0155)$ & $(.0155)$ & $(.0156)$ \\
Small Fund $\times$ Small Cap Fund & & .0795 & .0776 & .0796 \\
& & $(.0394)$ & $(.0395)$ & $(.0398)$ \\
Number of Funds in Family & & .0002 & \\
& & & $(.0002)$ & Yes \\
Momentum Effects & Yes & Yes & Yes & Yes \\
Book to Market Effects & Yes & Yes & Yes & Yes \\
Fund City Effects & Yes & Yes & Yes & Yes \\
Family Size Effects & No & No & No & \\
\hline
\end{tabular}

